\title{
Lightning fast interlibrary loan Using e-readers for on-demand delivery
}

A lthough this article is primarily about usage of a "new" technology in interlibrary loan (ILL), it is really much more. The bigger picture: the importance of developing and nurturing a sense of being persistently aware. Aware of what has passed, what is current, and what is on the horizon in the world of technology specifically, but also social and collaborative trends in the local community you serve.

Why? Because this is a powerful tool for shaping your library's future in all areas; budget, space, staffing, etc. Once you have consciously trained your brain to "be aware," you cannot turn it off. You will instinctually notice "new" or "different" things and ask yourself "How can we use this in the library?" or "How

- Kindles are available for check out to all UNO faculty/staff/students/alumni, and current Library Friends

- Patrons must sign a form before checkout

- Kindles may be placed on hold

- Check out period is for two weeks with one renewal if there are no holds placed on the Kindle

- Kindles are available for both ILL and general circulation

- ILL requests will have priority

- ILL patrons will have a choice between Kindle book or traditional book

- Kindles are for monograph use only

Figure 1. UNO's Kindle circulation policy. ies Stephen Shorb purchased three Kindles to experiment how, or if, they might be used in the library. Shorb suggested ILL as an ideal place to explore.

Before we were able to use the Kindle for ILL, we first had to tackle the technicalities of circulating an ereader. Loan rules, cataloging procedoes this impact our services?" Be the person who thinks of a new or different way to apply emerging trends and technology to new or current services. This form of thought is what led the University of Nebraska-Omaha (UNO) to use Amazon's Kindle ${ }^{1}$ for ILL.

Traditionally, ILL book (loan) requests can be filled in only two of the following three ways - fast, cheap, or easy. It could be fast and cheap, but not easy; could be fast and easy, but not cheap; could be cheap and easy, but not fast. With the arrival of e-readers and e-books, it is possible to have it all-fast, cheap, and dures, circulation policy (see fig. 1), acquisition policy, permission forms, and bags to protect the Kindle, were just a few of the questions needing answers.

Since we were pioneers in loaning ereaders, we had to invent the wheel. Without the right mindset- "I know this is possible, we just have to figure out the way"-we might

Joyce Neujahr is director of patron services at the Dr. C. C. and Mable L. Criss Library at the University of Nebraska-Omaha, e-mail: jneuhahr@unomaha.edu

(C) 2011 Joyce Neujahr 
have quit at the first hurdle. Not the least of which was national publicity concerning the legality of loaning the Kindle. Was it a violation of Amazon's ambiguous terms of service?

After discussing possible ramifications with Shorb, we decided to go ahead with our plan and view the purchase of Kindle titles as we do the purchase of a printed book. In other words, instead of an ebook living on a physical shelf, it is "shelved" on the Kindle. Originally, the Kindle was proprietary and the title loaded on a specific Kindle was to stay on only that Kindle. We followed that rule believing this conformed to current copyright rules and Amazon's terms of service. It is important to

\begin{tabular}{|l|c|c|}
\hline \multicolumn{1}{|c|}{ Title } & $\begin{array}{c}\text { Hardcover } \\
\text { Cost }\end{array}$ & $\begin{array}{c}\text { Kindle } \\
\text { Cost }\end{array}$ \\
\hline A Thousand Splendid Suns & 15.57 & 9.99 \\
\hline $\begin{array}{l}\text { Contemporary Debates in Cogni- } \\
\text { tive Science (Contemporary De- } \\
\text { bates in Philosophy) }\end{array}$ & 37.76 & 27.96 \\
\hline $\begin{array}{l}\text { Economic Growth, Income Distri- } \\
\text { bution and Poverty Reduction in } \\
\text { Contemporary China }\end{array}$ & 180.00 & 105.00 \\
\hline $\begin{array}{l}\text { For the Common Good? American } \\
\text { Civic Life and the Golden Age of } \\
\text { Fraternity }\end{array}$ & 17.43 & 5.51 \\
\hline $\begin{array}{l}\text { John Adams } \\
\text { John Skelton and Poetic Au- } \\
\text { thority: Defining the liberty to } \\
\text { speak }\end{array}$ & 88.49 & 82.11 \\
\hline $\begin{array}{l}\text { Morality in a Natural World: Se- } \\
\text { lected essays in Metaethics }\end{array}$ & 78.70 & 54.40 \\
\hline One of Ours & 60.20 & 2.39 \\
\hline The Gathering & 16.32 & 8.80 \\
\hline $\begin{array}{l}\text { The Social Life of Coffee: The Emer- } \\
\text { gence of the British Coffeehouse }\end{array}$ & 42.00 & 33.60 \\
\hline $\begin{array}{l}\text { The World is Flat: A brief bistory of } \\
\text { the twenty-first century }\end{array}$ & 28.50 & 9.40 \\
\hline Water for Elephants: A novel & 16.29 & 8.37 \\
\hline Savings = \$255.37 & $\mathbf{\$ 6 1 2 . 8 9}$ & $\mathbf{3 5 7 . 5 2}$ \\
\hline
\end{tabular}

Table 1. Cost comparison hardcover versus Kindle purchases. of an issue. focus is bestsellers and not research-intensive academic titles. Currently, Amazon has more than 950,000, e-books so this has become less

In the beginning, about 90 percent of patrons chose the traditional hardcover, even though they would have to wait. Reasons given for not using the Kindle included:

- "I don't want to learn a new technology; I already know how to use a book."

- "I need to be able to photocopy pages."

- "There is no approved citation style for e-books."

- "I want it on my own ereader."

All of the above issues have been resolved, even photocopying. (Yes, I actually note, Amazon has never contacted us; and if asked to stop, we would readily comply.

With policies and procedures in place, we began offering ILL book requests for immediate pickup in March 2008. When a book request is placed, ILL staff check Amazon's Web site for availability as a Kindle title. If successful, an e-mail is sent to the patron asking if they would like to receive their book traditionally in a few days, or if they would prefer to use the Kindle and have their request filled immediately. Initially, many of the requested titles were unavailable, as Amazon's tried making a photocopy of a page on the Kindle, and it worked). E-readers have become abundant. The Kindle is Amazon's bestselling item of all time, and, on May 19, 2011, Amazon announced they now sell more e-books than hardcover and paperbacks combined. "The share of adults in the United States who own an e-book reader doubled to $12 \%$ in May, 2011 from 6\% in November 2010." ${ }^{3}$ Citation styles have been developed, e-book page numbers now match the print version, and it is possible to deliver an e-book on a patron's choice of devices. 
If the patron responds affirmatively, ILL staff purchases the title and have the e-reader waiting at the circulation desk for pickup. ILL staff adds the title to the corresponding Kindle's bibliographic record. Circulation staff completes the transaction, including the patron reading and signing the check out form agreeing to be responsible for loss or damages to the Kindle.

The last, and very important, step in the check out process is to "de-register" the Kindle blocking the patron from purchasing anything on the library's account. This is a simple task and takes very little time. The Kindle is easily registered again when another purchase is needed.

Savings on select Kindle ILL titles compared to the printed price can be found in Table 1.

While we continue to offer the e-book ILL option, the majority of our Kindle checkouts come from our "Request a Title"
- 12 Kindles

- Total circulation as of 4/19/10: 360

- Total circulation as of 9/12/10: 424

- Total circulation as of 7/25/11: 584

- Average $=49$ checkouts per Kindle
Figure 2.UNO's Kindle circulation statistics. However, when viewed service. Patrons come to the circulation desk and request a title we do not own, and while they are standing at the desk, we purchase their book on an available Kindle. The majority of these titles are popular fiction; a genre which most academic libraries spend very little money. Circulation staff is authorized to spend up to $\$ 50$ per title, and only one title request per patron is allowed.

We wanted the Kindle titles and authors to be searchable, so we chose to create a bibliographic record for each Kindle device and attach titles to that specific Kindle's bibliographic record. Circulation staff adds the newly purchased title to the bib record in the 700 field (alternate author, alternate title). Amazon now allows sharing of titles among six Kindles purchased on the same account, so the proprietary rule is no longer of consequence.

There is one more option we offer our patrons: loaning the hardware. A patron can checkout the Kindle, register it with their Amazon account information, and purchase whatever they would like. When they return as a one time purchase

the Kindle we delete everything we do not own, and the patron still has access to all the content via his or her own device. Very few of haps marketing would increase usage, but at this point all the Kindles are typically checked out with holds placed on them (see fig. 2).

Looking forward, UNO will not purchase additional e-readers. It is less about hardware now, and more about content. Our efforts are with negotiating and acquiring e-content, which allows convenient access to our patrons when they want it and on a device of their choice.

Springer is currently the only publisher offering an option with ILL privileges, multiuser options, and perpetual ownership. I applaud their recognition of library needs and hope others will follow their lead. Yes, purchase of the Springer package is expensive. and the main concerns of librarians are adconsideration; especially taking into account the savings in postage costs, packing material, and staff time saved in ILL by eliminating the associated costs of mail handling.

Using UNO as an example, our student worker spends approximately 14 hours a week taking care of all incoming and outgoing mail. $\$ 7.50 /$ hour ( $\$ 105 /$ week) is spent on staff's salary. Monthly mailing supplies, including shipping labels, DVD mailers, and packing tape average $\$ 135 /$ month. Monthly charges from our mail department average $\$ 1,373 /$ month. Total average cost per month for lending and borrowing books is $\$ 1,928 /$ month or $\$ 23,136$ / year. Time spent pulling requested books for lending is not included in this calculation.

\section{Conclusion}

In retrospect, using e-readers for ILL and general circulation has been very successful.

(continues on page 541) our patrons take advantage of this option. Perdressed reasonably well, the offer deserves 
writing process, due in large part to working with their primary source. "It's as though I was on a moving platform. A good foundation that would help move the story forward when I got a block," one student said.

Others found that the primary source significantly helped develop elements of the story: "As the author, I was able to portray more dynamic characters and experiences because I felt connected to a real event and time." One student became so tied to the primary source that writing about it became a very personal experience: "It felt close to home for me so I worked hard to make sure I did it justice at least."

\section{Encouraging lifelong research and writing}

We hope that the experience will foster long term practices of creative writing and ongoing use of archival collections. When we asked at the end of the course, almost half of our students said they plan to work on their stories in the future, while others were much more certain that they would revisit this story or even start a new one. "Maybe over the summer!" said one student.

Others said that they would not continue working on their stories, citing reasons such as lack of time or, as one student stated, "creative writing is not my thing." At the very least, students gained an appreciation of the writing process itself: "I now appreci- ate what writers do, and how hard their jobs actually are."

While most students do not anticipate using the archives again as undergraduates unless it is required in a class, most expressed positive experiences using the facility: "I think it's quite interesting," reported one student.

The assignment proved valuable as it encouraged students to conduct original research and gave them insight into an often underused resource. They learned the fundamentals of what archives hold, the difference between archives and libraries, and the basics of accessing, understanding, and using primary source materials. Furthermore, many gained an appreciation of the unique treasures contained in an archives: "[I]t was an experience you can't get from anything else .... to actually hold the documents in your hand is an unparallel[ed] experience."

For us, the project was successful on all levels. When we teach the class again, we will spend even more time searching for sources in the archives and talking about writing during class. We want to provide students with the time and space to unlock their creativity in both researching and writing. Our goal is for all students to have an experience similar to this one: "The project as a whole was an excellent idea-I've never done anything like it before. It really let my imagination run wild." $n$
("Lightening fast ..." continued from page 533)

One thing I would do differently, however, is instead of purchasing so many first generation Kindles, I would wait and purchase more of the second and third generations. Hard to believe, but the first generation, almost four years old, looks like ancient technology compared to the second and third generations.

For now, UNO will continue loaning Kindles, both for ILL and regular circulation, as long as our patrons continue to use them and as we evolve into the next transformation-whatever that may be.

\section{Notes}

1. UNO's use of the Kindle does not constitute an endorsement of this product.

2. Kit Eaton, "Amazon sells more e-books than paper ones," Fastcompany.com, http:// www.fastcompany.com/1754259/amazondeclares-the-e-book-era-has-arrived (accessed Sept. 15, 2011).

3. Kristen Purcell, Pew Internet, "E-reader ownership doubles in six months," http:// pewinternet.org/Reports/2011/E-readers-and -tablets/Report.aspx (accessed July 6, 2011). n 